\title{
Kegiatan Inklusi Sosial di Perpustakaan Ganesha SMA N 1 Jetis Bantul
}

\author{
Dian Fitri Ningrum \\ Perpustakaan SMA N 1 Jetis Bantul \\ email: dianofficial11@gmail.com
}

\begin{abstract}
Abstrak
Perpustakaan Ganesha telah terkareditasi A yang merupakan perpustakaan sekolah SMA N 1 Jetis Bantul yang beralamat di Jln Imogiri Barat KM 11 Kertan Sumberagung Jetis Bantul Yogyakarta 55781. Kegiatan inklusi sosial merupakan suatu layanan yang ada diperpustakaan Ganesha. Adanya kegiatan inklusi sosial diharapkan dapat memberi dampak positif pada masyarakat sekitar, serta mendekatkan koleksi pada masyarakat. Adanya program yang diadakan secara berkala dan berkesinambungan akan mengoptimalkan pengertahuan masyarakat tentang ilmu-ilmu yang dibutuhkan. Tujuan penelitian yang dilaksanakan adalah untuk mengetahui manfaat kegiatan inklusi sosial di perpustakaan Ganesha. Kegiatan inklusi sosial yang terdapat di perpustakaan Ganesah SMA N 1 Jetis antara lain; Olah Aloe, Pelatihan Membatik, Pendampingan BelajarYaketunis, Literasi Religi, serta Gerobak Literasi. Sasaran kegiatan inklusi sosial Perpustakaan Ganesha SMA N 1 Jetis adalah warga sekitar sekolah, hingga warga se-kabupaten Bantul. Dalam penelitian ini peneliti menggunakan metode observasi langsung dengan melihat data statistik pengunjung dan data koleksi dipinjam dan wawancara dengan pustakawan perpustakaan Ganesha. Segala kegiatan Perpustakaan Ganesha dapat dilihat di akun sosial media Instagram @perpus_ganesha atau mengakses informasi koleksi di web http://lib.sman1jetis.sch.id. Dari hasil riset membuktikan bahwa dengan adanya kegiatan inklusi sosial dapat meningkatkan pengunjung perpustakaan dan jumlah koleksi yang dipinjam secara signifikan
\end{abstract}

\section{Kata Kunci:}

Inklusi sosial layanan

Perpustakaan Ganesha

\section{A. PENDAhULUAN}

Kebutuhan informasi yang saat ini menjadi bagian pokok dari kehidupan manusia telah mengalami perkembangan. Informasi yang dibutuhkan siswa maupun masyakarat, sebagai salah satu anggota perpustakaan sekolah. Mayarakat yang belum mendapatkan ruang untuk belajar akan merasa kekurangan dalam hal informasi. Perpustakaan sekolah saat ini juga mulai mencanangkan program Perpustakaan Nasional Republik Indonesia tentang progam inklusi sosial. Program yang melibatkan masyarakat dalam memanfaatkan fasilitas serta layanan sehingga mencapai kemajuan dalam bidang segala.

Sekolah sebagai sebuah institusi pendidikan merupakan tempat pembelajaran yang memberi pengajaran dan fasilitas sumber-sumber informasi.
Perpustakaan sekolah sebagai salah satu fasilitas sekaligus sarana penunjang siswa, menyediakan beragam informasi yang sesuai dengan kebutuhan penggunanya. Menyimpan berbagai koleksi cetak maupun non cetak yang dapat menunjang siswa dalam kegiatan belajar mengajar. Koleksi yang yang terdapat dalam perpustakaan sekolah bukan hanya berupa koleksi pelajaran, akan tetapi juga ditunjang dengan koleksi non pelajaran. Hal ini untuk menunjang proses kreatif siswa dalam bidang non akademik.

Pemanfaatan fasilitas serta layanan perpustakaan sekolah tentunya berkaitan dengan waktu layanan yang disediakan masing-masing perpustakaan. Dalam hal ini perpustakaan sekolah dianjurkan untuk menyediakan waktu yang cukup untuk melayani pemustaka agar pemustaka dapat 
dengan leluasa memanfaatkan fasilitas serta layanan yang tersedia. Pemustaka dalam perpustakaan sekolah antara lain peserta didik, tenaga pendidik, tenaga kependidikan, maupun anggota lain. Anggota lain adalah msyarakat di luar civitas sekolah seperti, alumni, peserta didik kesetaraan, pengurus komite sekolah, orang tua/wali peserta didik, serta masyarakat umum. Pemustaka anggota lain dapat memanfaatkan sumber-sumber koleksi perpustakaan sekolah didasarkan pada prinsip umum pemanfaatan informasi.

Fasilitas dan layanan yang tersedia dalam perpustakaan sekolah tentunya akan kurang maskimal tanpa adanya kegiatan promosi. Pengelola harus aktif dan secara terus menerus melakukan promosi perpustakaannya agar pemustaka termasuk anggota lain dapat mengetahui dan memafaatkan fasilitas serta layanan yang dimiliki perpustakaan sekolah. Promosi perpustakaan adalah upaya untuk mengenalkan seluruh aktivitas yang ada dalam perpustakaan sekolah dalam beberapa aspek seperti, layanan, koleksi, kegiatan, fasilistas dan sebagainya.

Promosi perpustakaan sekolah tentunya memiliki perbedaan antara satu dan yang lainnya, hal ini terkait dengan karakteristik sekolah dan kesesuaian dengan program yang telah disusun. Dengan adanya kegiatan promosi perpsutakaan, diharapakan peran perpustakaan sekolah tidak hanya dapat mencerdasakan civitas sekolah akan tetapi dapat memberi manfaat untuk warga sekitar.

Promosi perpustakaan Ganesha SMA N 1 Jetis Bantul adalah dengan adanya layanan berbasis masyarakat. Layanan yang dihadirkan Perpustakaan Ganesha SMA N 1 Jetia Bantul merupakan kegiatan inklusi sosial untuk masyarakat sekitar. Layanan ini bertujuan untuk meningkatkan kehidupan masyarakat melalui literasi. Selain melalui layanan kunjungan, perpustakaan Ganesha SMA N 1 Jetis Bantul juga melaksanakan kegiatan pelatihan, agar literasi yang telah didapatkan melalui membaca buku dapat dipraktikkan dalam kehidupan nyata sehingga masyarakat dapat meningkatkan taraf kehidupannya. Tujuan dalam penelitian ini adalah : (1) Untuk mengetahui pentingnya kegiatan inklusi sosial di Perpustakaan Ganesha SMA N 1 Jetis Bantul. (2) Untuk mengetahui kegiatan inklusi sosial yang terdapat di Perpustakaan Ganesha SMA N 1 Jetis Bantul.

Berdasarkan latar belakang di atas, penulis dapat menyimpulkan rumusan masalah sebagai berikut:

1. Mengapa perlu diadakan kegiatan inklusi sosial di Perpustakaan Ganesha SMA N 1 Jetis Bantul?

2. Kegiatan inklusi sosial apa saja yang terdapat di Perpustakaan Ganesha SMA N 1 Jetis Bantul?

\section{B. KAJIAN TEORITIS}

Engking Mudyana dan Royani dalam Dian Sinaga (2005) Perpustakaan sekolah ialah sarana penunjang pendidikan yang bertindak sebagai pelestari ilmu pengetahuan, dan di lain pihak sebagai sumber bahan pendidikan yang akan diwariskan kepada generasi yang lebih muda. Secara nyata perpustakaan sekolah merupakan sarana untuk proses belajar dan mengajar bagi guru maupun bagi murid. Menurut Pergub DIY No. 18 Tahun 2018 perpustakaan sekolah adalah perpustakaan yang terdapat dalam satuan formal pendidikan dari pendidikan dasar dan menengah dan merupakan bagian kesatuan sekolah tersebut guna mencapai tujuan yang di telah ditentukan. Beberapa kegiatan dalam perpustakaan sekolah adalah pengelolaan perpustakaan sekolah yang meliputi Organisasi, Tenaga Koleksi, Layanan, Sarana Prasarana, Pengembangan Minat dan Budaya baca di Sekolah Kerjasama, Teknologi Informasi, Evaluasi Penyelenggaraan, dan Pembinaan.

Pendapat dari Lasa (2016) menjelaskan bahwa perpustakaan sekolah adalah perpustakaan yang berada pada satuan pendidikan formal di lingkungan 
pendidikan dasar dan menengah yang merupakan bagian integral dan merupakan satu kesatuan dari dari kegiatan sekolah yang bersangkutan dan merupakan pusat sumber belajar untuk mendukung tercapainya tujuan pendidikan sekolah sesuai tujuan masing-masing. Setiap jenjang sekolah wajib menyelenggarakan perpustakaan sekolah yang dikelola secara professional sesuai standar nasional dan memerhatiakn standar Nasional Pendidikan, memiliki buku teks, melayani pendidik dan peserta didik, menerapkan teknologi informasi dan komunikasi, dan memiliki anggaran sekurangkurangnya 5\% dari anggaran operasional sekolah. Dian Sinaga (2007) menyatakan, "perpustakaan sekolah adalah perpustakaan yang berisi koleksi buku-buku yang diorganisasi, berada di sebuah sekolah untuk menunjang proses belajar-mengajar. Perpustakaan sekolah berguna untuk menunjang tercapainya target kurikulum. Oleh karena itu perpustakaan sekolah merupakan bagian vital dan sebagai sarana yang multi-kompleks dalam system pendidikan di negara.

Dari beberapa pendapat di atas dapat disimpulkan bahwa perpustakaan sekolah adalah unit yang bersangkutan dengan pelestarian serta pengelolaan koleksi cetak maupun non cetak yang dapat menunjang proses belajar mengajar siswa maupun guru.

Adanya perbedaan masyarakat baik dari usia, suku, jenis kelamin, agama, kebangsaan, Bahasa dan status sosial terkadang menjadikan jarak antara masyarakat dengan lembaga lain. Hal ini tentunya akan berpengaruh pada kemajuan dalam berbagai bidang. Eksklusi sosial adalah kondisi dimana ketidakmampuan suatu komunitas atau masyarakat untuk menghimpun semua golongan menjadi satu kesatuan secara utuh dalam Muhammad Usman Noor (Power \& Wilson, 2009). Ada pemisahan yang dilakukan di masyarakat baik itu melihat dari perbedaan pandangan, status sosial, gender atau apapun sehingga akhirnya menyebabkan ada golongan yang terpinggirkan dan termarginasilasi. Sehingga dapat disimpulkan bahwa inklusi sosial adalah kondisi dimana masyarakat dapat menyatukan seluruh komponen tanpa membedakan satu hal apapun. Semua sama dan bergabung dalam satu kesatuan. Terdapat beberapa jenis pengguna perpustakaan yang sering terekslusi sebagai contoh adalah etnis minoritas, pengungsi, pengguna berkebutuhan khusus, dan orang-orang yang tidak keluar rumah karena kondisinya dalam Muhammad Usman Noor (McMenemy, 2009).

Menurut seorang Inggris organisasi dalam Man, Tso Hin (2007), Pusat Inklusi Ekonomi \& Sosial, telah mendefinisikan inklusi sosial sebagai proses di mana upaya dilakukan untuk memastikan bahwa setiap orang, terlepas dari mereka pengalaman dan keadaan, dapat mencapai potensi mereka dalam kehidupan. Proses yang memastikan bahwa mereka yang berisiko kemiskinan dan sosial pengecualian mendapatkan kesempatan dan sumber daya yang diperlukan untuk berpartisipasi sepenuhnya dalam kehidupan ekonomi, sosial dan budaya dan untuk menikmati standar hidup dan kesejahteraan yang dianggap normal dalam masyarakat tempat mereka tinggal.

Dari berbgai pendapat di atas dapat disimpulkan bahwa inklusi sosial adalah penyatuan masyarakat dalam satu unit kegiatan pemberdayaan dengan mengabaikan perbedaan status sosial, gender atau apapun. Sehingga dapat mensejahterakan kehidupan masyarakat selanjutnya.

\section{METODE PENELITIAN}

Metode penelitian adalah cara bagaimana suatu penelitian akan dilaksanakan. Hal ini dilakukan peneliti untuk mempermudah dalam mengumpulakan data, mengolah data, hingga menyajikan data dalam suatu hasil penelitian. Peneliti harus menentukan metode penelitiaanya sebelum melakukan penelitian agar mempermudah 
dalam langkah selanjutnya. Penulis menggunakan metode penelitian kualitatif, karena sesuai dengan objek yang akan dikaji. Menurut Andi Prastowo (2016) metode penelitain kualitatif adalah metode (jalan) penelitian yang sistematik yang digunakan untuk mengkaji atau meneliti suatu objek pada latar alamiah tanpa ada manipulasi di dalamnya dan tanpa ada pengujian hipotesis, dengan metodemetode yang alamiah ketika hasil penelitian yang diharapkan bukanlah generalisasi berdasarkan ukuran-ukuran kuantitas, namun makna (segi kualitas) dari fenomena yang diamati.

Teknik pengumpulan data adalah suatu metode yang dilakukan oleh peneliti atau tata cara yang peneliti gunakan dalam pengumpulan data penelitian agar mendapatkan hasil data yang relevan. Menurut Sugiono (2009) wawancara adalah pertemuan dua orang untuk bertukar informasi dan ide melalui tanya jawab sehingga dapat dikonstruksikan makna dalam suatu topik tertentu dan dengan wawancara, peneliti akan mengetahui hal-hal yang lebih mendalam tentang partisipan dalam menginterprestasikan situasi dan fenomena yang terjadi yang tidak mungkin bisa ditemukan melalui observasi. Supardi (2006) menyatakan bahwa metode observasi merupakan metode pengumpul data yang dilakukan dengan cara mengamati dan mencatat secara sistematik gejala-gejala yang diselidiki.

Pendapat dari Suharsimi Arikunto (2010), menyatakan bahwa instrumen pengumpulan data adalah alat bantu yang dipilih dan digunakan oleh peneliti dalam kegiatannya mengumpulkan data agar kegiatan tersebut menjadi sistematis dan dipermudah olehnya. Dalam hal ini penulis menggunakan metode pengumpulan data dengan cara observasi dan juga wawancara. Observasi dilakukan langsung dengan mengikuti serta membuat program perpustakaan berbasis inklusi sosial yang ada di perpustakaan Ganesha SMA N 1 Jetis Bantul. Sedangkan metode wawancara dilakukan dengan tanya jawab menggali informasi kepada pengelola serta kepala perpustakaan.

\section{HASIL DAN PEMBAHASAN}

\section{Pentingnya Kegiatan Inklusi Sosial di} Perpustakaan Ganesha SMA N 1 Jetis Bantul

Perpustakaan Ganesha merupakan perpustakaan sekolah SMA N 1 Jetis yang berada di Jalan Imogiri Barat, KM 11, Kertan, Sumberagung Jetis, Bantul. Perpustakaan ini sudah terakreditasi A sejak tahun 2018. Memiliki luas gedung sebesar $883.06 \mathrm{~m}^{2}$ dengan luas tanah sebesar $1396 \mathrm{~m}^{2}$. Dengan adanya fasilitas serta layanan yang melayani tidak hanya warga sekolah, adanya beberapa program kegiatan yang diperuntukkan untuk masyarakat juga menjadi unggulan perpustakaan Ganesha. Letak sekolah yang berdekatan dengan lingkungan masyarakat juga mendorong diadakannya program inklusi ocial. Hal ini diharapkan dapat membantu serta mendekatkan perpustakaan dengan masyarakat sehingga literasi tidak hanya di kalangan sekolah.

Guna mendukung program perpustakaan nasional tentang program inklusi ocial yang terintegrasi dengan perpustakaan, maka Perpustakaan Ganesha mencoba hal tersebut. Hal ini didukung dengan juga dengan adanya fasilitas serta layanan khusus program inklusi ocial. Dengan didukung oleh komitemen pimpinan serta semua aspek, perpustakaan Ganesha berharap dapat memberi manfaat untuk warga sekitar.

Beragam masyarakat dari berbagai lapisan, usia, serta profesi juga menjadi obyek kami untuk melaksanakan program tersebut. Beberapa organisasi seperti karangtaruna, PKK dusun, serta kaum difabel juga menjadi mitra perpustakaan Ganesha. Keterbatasan waktu dan biaya, adalah salah satu ocial masyarakat mengkuti kegiatan ini. Oleh karena itu, dengan diadakannya program inklusi ocial dapat memberi kemudahan akses dalam memanfaatkan perpustakaan Ganesha. 
Aplikasi dari kegiatan iknlusi ocial adalah setelah masyarakat selesai membaca kemudian diadakan program pelatihan. Sehingga ilmu yang didapat dari membaca dapat diaplikasikan dikehidupan nyata. Harapannya adalah dapat meningkatnya kehidupan masyarakat setelah membaca serta belajar di perpustakaan Ganesha SMA N 1 Jetis.

\section{Kegiatan Inklusi Sosial di Perpustakaan Ganesha SMA N 1 Jetis Bantul}

Ada beberapa kegiatan inklusi sosial di Perpustakaan Ganesha SMA N 1 Jetis yang telah terlaksana dengan baik. Kegiatan inklusi sosial diawali dengan membentuk sebuah program yang disesuaikan dengan karakteristik masyarakat. Secara lebih rinci kegiatan inklusi sosial yang terdapat di Perpustakaan Ganesha adalah sebagai berikut:

\section{a. Olah Aloe}

Kegiatan Olah Aloe dilaksakan bersama ibu-ibu PKK Dusun Ponggok. Sebagai salah satu bentuk layanan yang diberikan pada masyarakat terkait dengan pendayagunaan koleksi perpustakaan Ganesha. Kegiatan ini dimulai dari adanya pengarahan dari narasumber, hingga pelatihan membuat olahan dari Aloe Vera. Kegiatan ini dilakukan di green library Perpustakaan Ganesha SMA N 1 Jetis.

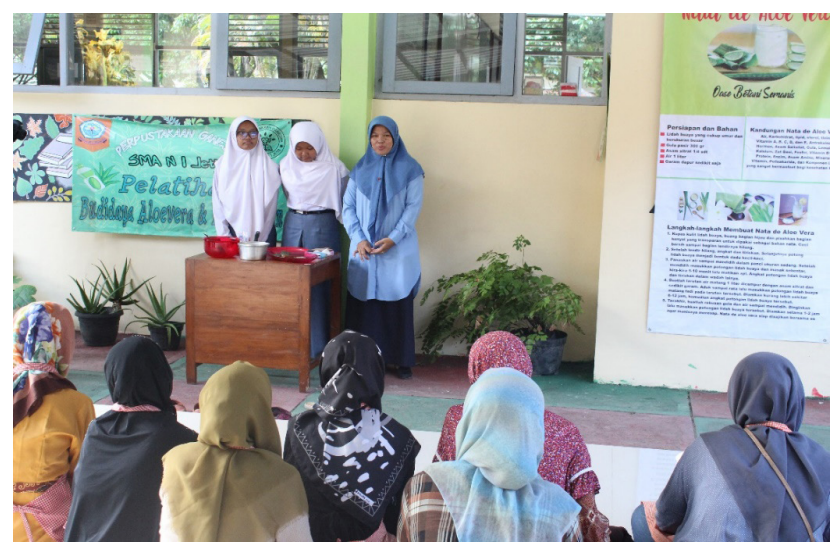

Gambar 1. Kegiatan Olah Aloe bersama karang taruna PKK Dusun Ponggok, Bantul

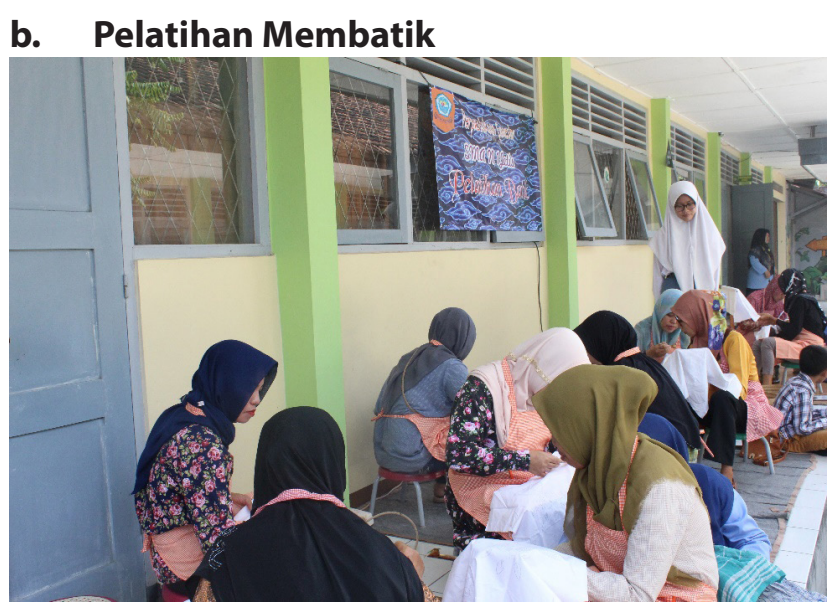

Gambar 2. Kegiatan pelatihan membatik dengan Ibu-ibu PKK Dusun Ponggok, Bantul

Pelatihan membatik untuk Karangtaruna Dusun Ponggok dilakukan di oase batik, pelatihan membatik diawali dengan membaca koleksi di perpustakaan, lalu membuat pola batik dan proses membatik.

Yaketunis, Yayasan Kesejahteraan Tuna Netra Islam yang berlamat di Jl. Parangtritis No.46, Danunegaran, Kec. Mantrijeron, Kota Yogyakarta, Daerah Istimewa Yogyakarta 55143 adalah mitra Perpustakaan Ganesha, pendampingan belajaryang dilakukan oleh KOMPUSTA (Komunitas Pustakawan Taruna) adalah salah satu bentuk kegiatan inklusi sosial. Kegiatan ini dilakukan dengan cara membawa koleksi yang terdapat di perpustakaan Ganesha, kemudian dibacakan di Yaketunis. Koleksi yang dibawa adalah koleksi yang diinginkan siswa Yaketunis. 


\section{c. Pendampingan Belajar dengan Yaketunis}

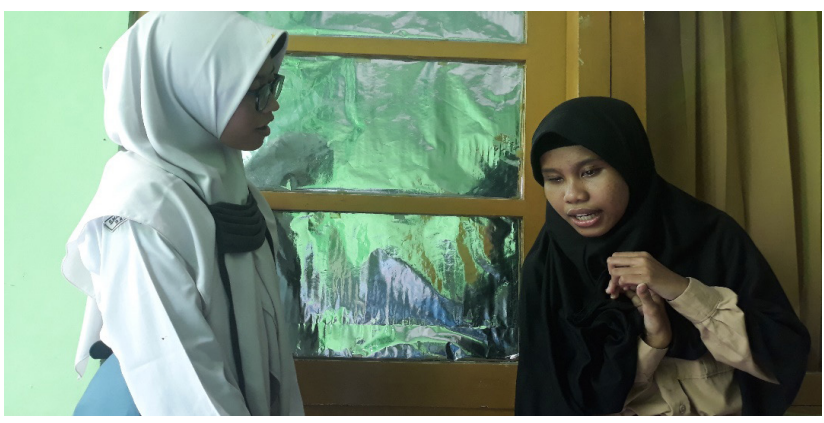

Gambar 3. Kegiatan pendampingan belajar antara KOMPUSTA dengan siswa Yaketunis

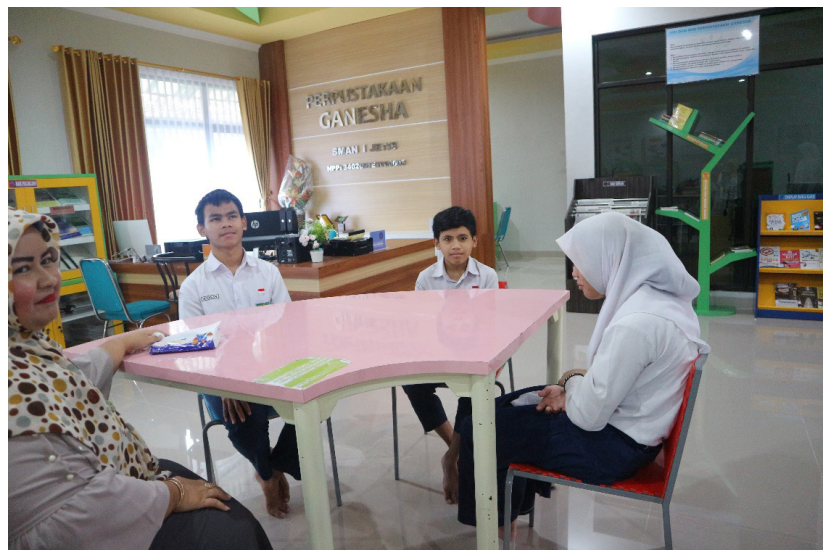

Gambar 4. Kunjungan siswa Yaketunis ke Perpustakaan Ganesha dalam rangka kegiatan bioskop berbisik

\section{d. Literasi Religi}

Kegiatan Literasi Religi diadakan pada saat momentum ramadhan, ketika anak- anak serta masyarakat menanti waktu buka bersama, maka perpustakaan Ganesha mengadakan kegiatan literasi religi. Ada beberapa siswa yang bertugas untuk membuka area baca terbuka. Beberapa koleksi yang dibawa antara lain, koleksi anak, koleksi-koleksi agama serta koleksi yang lain. Kegiatan ini bertujuan untuk meningkatkan layanan pada masyarakat sekaligus mendekatkan koleksi pada masyarakat. Masyarakat secara gratis membaca buku di kegiatan tersebut, akan tetapi buku hanya bisa dibaca di tempat.

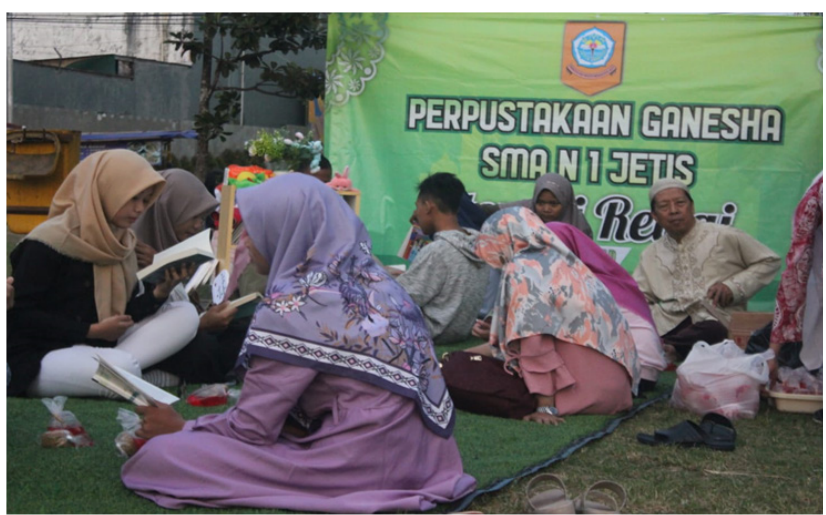

Gambar 5. Literasi religi perpustakaan

Ganesha di Lapangan Paseban Bantul

\section{e. Gerobak Literasi}

Gerobak Literasi diadakan setiap hari Minggu satu kali dalam sebulan, dilaksanakan di Lapangan Sultan Agung Bantul. Kegiatan Gerobak Literasi juga hampir sama dengan Literasi Religi. Gerobak Literasi menggunakan alat transportasi tradisional gerobak sapi untuk membawa buku, sehingga hal ini dapat menjadi daya tarik mayarakat. Selain dapat membaca buku, masyakarat juga dapat bermain di gerobak sapi secara gratis.

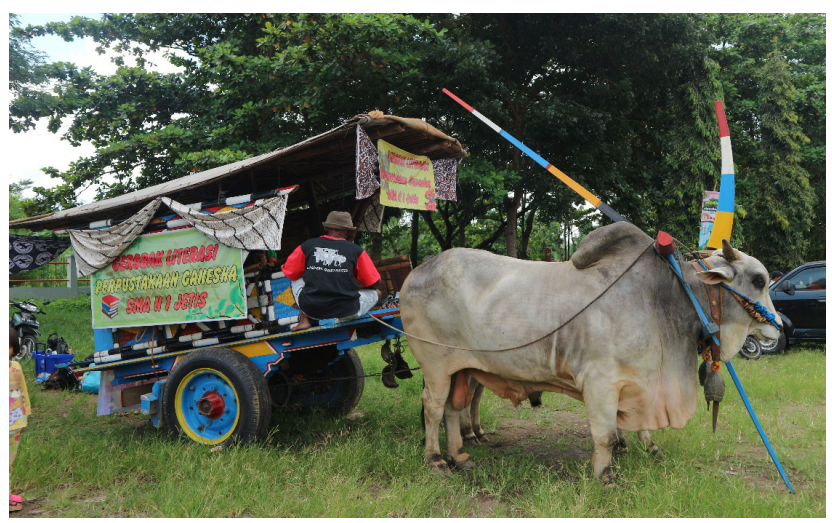

Gambar 6.Gerobak literasi perpustakaan

Ganesha di Stadion Sultan Agung Bantul

Sumber: Dokumen pribadi Perpustakaan Ganesha 2019

Pada penelitian yang dilakukan oleh Yoga Yanuar Prasetyawan dan Patut Suharto (2015) yang dilakukan di masyarakat Taruna Bhakti Banjarbaru menyatakan bahwa literasi inklusi 
yang dilaksanakan meningkatkan minat baca masyarakat, hal ini terbukti dengan adanya peningkatan jumlah pengunjung di perpustakaan desa setempat. Dalam penelitian ini, peneliti mencoba meneliti tentang kegiatan inklusi sosial di perpustakaan sekolah. Peningkatan minat baca pada perpustakaan Ganesha terkait dengan adanya kegiatan inklusi sosial dapat dilihat dari jumlah kunjungan masyarakat dan jumlah buku yang dibaca oleh masyakarat. Hal ini dapat dibuktikan dengan data jumlah pengunjung dan jumlah pembaca/peminjam dalam tiga bulan terakhir.

Tabel 1

Data Jumlah pengunjung Perpustakaan

\begin{tabular}{|c|c|c|c|c|c|}
\hline & & esha tig & ulan & akhir & \\
\hline \multirow{2}{*}{ No } & \multirow{2}{*}{ Bulan } & \multicolumn{4}{|c|}{ Jumlah Pengunjung } \\
\hline & & Anggota & $\%$ & Non Anggota & $\%$ \\
\hline 1 & Februari 2019 & 1253 & - & 54 & - \\
\hline 2 & Maret 2019 & 2.146 & 41,61 & 103 & 47,57 \\
\hline 3 & April 2019 & 4.070 & 47,27 & 152 & 32,24 \\
\hline & Jumlah & 7.469 & - & 264 & - \\
\hline
\end{tabular}

Sumber: Data Perpustakaan Ganesha 2019

Pada Tabel 1 tampak bahwa, dengan adanya program inklusi sosial terbukti ada dampak positif terjadinya peningkatan jumlah pengunjung. Peningkatan pengunjung tertinggi terdapat pada pengunjung dari kelompok non anggota sebesar 47,57\% pada bulan Maret 2019. Sementara pengunjung dari kelompok anggota terjadi peningkatan pada bulan April 2019 sebesar 47,27\%.

Pada Tabel 2 tampak bahwa, dengan adanya program inklusi sosial terbukti ada dampak positif dan negatif yakni terjadinya penurunan jumlah koleksi dipinjam oleh kelompok anggota, terdapat penurunan antara 10,54\% - 18,64\% berdasarkan judul dan angka 6,79\% - 17,75\% berdasarkan eksemplar. Disisi lain bagi pembaca dari kelompok non anggota terdapat peningkatan jumlah koleksi dibaca yaitu antara 23,08\% - 50,00\% berdasarkan judul dan 32,26\% - 66,67\% berdasarkan eksemplar. Dari hasil wawancara dengan pustakawan Perpustakaan Ganesha, terjadinya penurunan koleksi yang dipinjam oleh siswa terjadi pada bulan Maret dan April, disebabkan pada bulan itu para siswa disibukkan dengan persiapan ujian sekolah/ ujian akhir sekolah. Apabila dihubungkan dengan tingkat kunjungan siswa ke perpustakaan, hal ini ada korelasi adanya tingkat kunjungan yang meningkat pada bulan Maret-April 2019 tersebut, dimana pada bulan itu para siswa berkunjung ke perpustakaan dalam rangka untuk belajar dalam mempersiapkan ujian akhir sekolah.

Tabel 2

Data Jumlah peminjam dan pembaca
\begin{tabular}{|c|c|c|c|c|c|c|c|c|c|}
\hline \multirow{2}{*}{ No } & \multirow{2}{*}{ Bulan } & \multicolumn{7}{|c|}{ Anggota } & \multicolumn{5}{c|}{ Numlah Peminjam/pembaca } \\
\cline { 3 - 11 } & Judul & $\%$ & Eksemplar & $\%$ & Judul & $\%$ & Eksemplar & $\%$ \\
\hline 1 & $\begin{array}{l}\text { Februari } \\
2019\end{array}$ & 560 & - & 677 & - & 5 & - & 7 & - \\
\hline 2 & $\begin{array}{l}\text { Mar et } \\
2019\end{array}$ & 501 & 10,54 & 631 & 6,79 & 10 & 50,00 & 21 & 66,67 \\
\hline 3 & $\begin{array}{l}\text { A p r r i } \\
2019\end{array}$ & 410 & 18,64 & 519 & 17,75 & 13 & 23,08 & 31 & 32,26 \\
\hline Jumlah & $\mathbf{1 . 4 7 1}$ & - & $\mathbf{1 . 8 2 7}$ & - & $\mathbf{2 8}$ & - & $\mathbf{5 9}$ & - \\
\hline
\end{tabular}

Sumber: Data Perpustakaan Ganesha 2019

Hasil studi ini selaras dengan hasil kajian Amanda Harrison dkk (2017) yang menyatakan perpustakaan akademis semakin terlibat dalam media sosial untuk terhubung dengan berbagai kelompok masyarakat dan bergerak melampaui batas-batas tradisional perpustakaan. Penelitian ini menggunakan pendekatanfenomenologis danTeori Kelembagaan untuk mengeksplorasi posting media sosial di enam perpustakaan universitas negeri dan swasta di dua negara bagian Midwest. Penelitian ini membahas tema apa yang muncul di antara halaman media sosial perpustakaan universitas dan apa, jika ada, perbedaan tema yang muncul berdasarkan status perpustakaan tersebut. Posting 
media sosial mencakup sepuluh kode berbeda: arsip; koleksi; acara; pameran; fasilitas; komunitas perpustakaan; sentimen; jasa; manajemen situs; dan komunitas universitas. Kode-kode ini terikat pada tiga tema berbeda: perpustakaan menciptakan rasa penjangkauan dan advokasi dengan tujuan membangun koneksi komunitas, menyediakan lingkungan yang mengundang, dan akses ke konten sesuai kebutuhan atau keinginan. Pada akhirnya, sementara perpustakaan di universitas dengan perpustakaan ARL atau program gelar MLS menunjukkan kerusakan yang sama antara ketiga tema ini, perpustakaan di lembaga gelar master lainnya menghabiskan lebih sedikit waktu untuk membuat koneksi komunitas sebagai pengganti posting konten dan informasi tentang lingkungan perpustakaan. Sementara Safirotu Khoir dkk (2017) menjelaskan modal sosial dapat dilihat sebagai kontributor penting bagi pemukiman imigran dalam masyarakat multikultural. Untuk imigran Asia di Australia, yang sebagian besar datang dengan modal manusia tingkat tinggi, penggunaan layanan perpustakaan dapat membantu menghasilkan bentuk modal sosial baru yang memfasilitasi proses penyelesaian dan membantu mereka mengatasi tantangan yang terkait dengan penyelesaian. Tercatat bahwa hubungan sebab akibat antara penggunaan perpustakaan umum oleh imigran dan modal sosial tidak ditetapkan. Namun demikian, faktor-faktor yang berkontribusi dalam generasi modal sosial diidentifikasi. Perpustakaan umum diharapkan untuk menciptakan layanan perpustakaan yang lebih baik untuk populasi imigran baik di tingkat linguistik dan budaya, memastikan mereka memenuhi mandat mereka untuk mendorong pembentukan modal sosial. Mengingat tidak adanya studi sebelumnya yang memeriksa imigran dengan sumber daya manusia yang ada, studi ini memberikan pemahaman yang lebih baik tentang nilai layanan perpustakaan umum untuk imigran dalam mendukung penyelesaian mereka. Hasilnya juga memberikan bukti kontekstual dengan menggambarkan hubungan timbal balik antara perpustakaan umum dan imigran dalam pembentukan aset sosial yang dapat diandalkan. Penelitian berbasis bukti ini menawarkan wawasan berharga dan memicu kesadaran akan perlunya perpustakaan umum dan layanan sosial untuk menyediakan imigran dengan layanan yang dirancang khusus untuk masyarakat. Penelitian di masa depan harus mengeksplorasi karakteristik imigran Asia secara lebih mendalam untuk menentukan apakah negara asal, usia, jenis kelamin, dan pendidikan memengaruhi penggunaan perpustakaan dalam mendukung proses penyelesaian. Menjangkau imigran yang tidak menggunakan layanan perpustakaan juga penting dan investigasi di masa depan dapat mengeksplorasi orang-orang yang tidak terjangkau, dan mengarah pada pemahaman yang lebih baik tentang perilaku mereka sehingga merancang program penjangkauan yang lebih tepat.

\section{E. PENUTUP \\ Simpulan}

Perpustakaan Ganesha SMA N 1 Jetis Bantul sudah menerapkan beberapa kegiatanyang berbasis inklusi sosial. Kegiatan inklusi sosial perpustakaan Ganesha antara lain; olah aloe, pelatihan membatik, pendampingan belajar Yaketinis, literasi religi, dan gerobak literasi. Hal ini bertujuan mendekatkan peran serta fungsi perpustakaan untuk mendukung budaya baca dan literasi masyarakat, serta kegiatan ini bertujuan untuk mendekatkan koleksi ke masyarakat. Dengan adanya kegiatan inklusi sosial, diharapkan dapat memberi pengaruh serta dampak yang baik untuk kehidupan selanjutnya. Kegiatan inklusi sosial yang ada di perpustakaan Ganesha SMA N 1 Jetis dilakukan secara berkelanjutan, sehingga masyarakat dapat mengikuti kegiatan dengan optimal. 


\section{Saran}

Agar kegiatan perpustakaan berbasis inklusi sosial dapat berjalan dengan baik maka masih perlu adanya pengembangan, kegiatan yang beragam, memprogramkan kegiatan yang sesuai dengan karakteristik masyarakan sekitar dan alokasi waktu yang tepat tentunya akan mengoptimalkan hasil kegiatan inklusi sosial yang diadakan.

\section{DAFTAR PUSTAKA}

Anonim. 2018. Peraturan Gubenrnur Daerah Istimewa Yogyakarta Nomor 18 Tahun 2018. Yogyakarta: DPAD-DIY.

Arikunto, Suharsimi. 2010. Prosedur Penelitian Suatu Pendekatan Praktik. Yogyakarta: Rineka Cipta.

Harrison, Amanda dkk. 2017. Social Media Use in Academic Libraries: A Phenomenological Study. The Journal of Academic Librarianship Volume 43, Issue 3, May 2017, Pages 248-256.

Khoir, Safirotu dkk. 2017. Contributing to social capital: An investigation of Asian immigrants' use of public library services. Library \& Information Science Research Volume 39, Issue 1, January 2017, Pages 34-45.

Lasa. H.S. 2016. Manajemen Perpustakaan Sekolah/ Madrasah. Yogyakarta: Ombak.

Man, Tso Hin. 2007. Sosial inclusion and public libraries: Is the ability to empathise an essential attribute for community librarians to better serve their ethnic minority users? A case study of Highfield Library and its Chinese community. Universitas of Sheffield.

Noor, Muhammad Usman. 2019. Aplikasi Layanan InformasiBerbasis InternetuntukMenumbuhkan Inklusi Sosial di Perpustakaan Daerah. JIPI (Jurnal IImu Perpustakaan dan Informasi). Vol. 4 No. 1 Tahun 2019 ISSN (online): 2528-021X.

Prasetyawan, Yanuar Yoga \& Patut Suharto. 2015. Inklusi Sosial dan Pemberdayaan Masyarakat dalam Pembangunan Perpustakaan Desa.
Prastowo, Andi. 2016. Metode Penelitian Kualitatif: dalam Perpspektif Rancangan Penelitian. Yogyakarta: Ar-Ruzz Media.

Sinaga, Dian. 2007. Mengelola Perpustakaan Sekolah. Bandung: Kiblat.

Sugiono. 2009. Metode Penelitian Pendekatan Kuantitatif, Kualitatif dan $R \& D$. Bandung: Alfabeta.

Supardi, M.d. 2006. Metodologi Penelitian. Mataram : Yayasan Cerdas Press.

Acarya Pustaka Volume 1, No. 1, Juni 2015. 